\title{
DAMPAK TARIF IMPOR OUTPUT DAN INPUT TERHADAP PROBABILITAS PERUSAHAAN KELUAR DARI PASAR
}

\author{
Impact of Output and Input Import Tariff on Firm Exit From Market
}

\author{
Windi Agustin Maulina, Arie Damayanti \\ Program Pasca Sarjana IImu Ekonomi, Universitas Indonesia \\ JI Prof. Dr. Sumitro Djojohadikusumo, Depok, Jawa Barat, 16424, Indonesia \\ Email: windi am@bps.go.id
}

Naskah diterima: 28/09/2018; Naskah direvisi: 01/02/2019; Disetujui diterbitkan: 20/06/2019

Dipublikasikan online: 31/07/2019

\begin{abstract}
Abstrak
Secara teori, dampak tarif impor input dan output terhadap kinerja perusahaan berbeda. Namun, hal tersebut belum terbukti secara empiris di Indonesia. Penelitian ini bertujuan menganalisis dampak tarif impor output dan input terhadap probabilitas perusahaan untuk keluar dari pasar. Kajian ini menggunakan model probit yang merupakan salah satu model dari Cummulative Distribution Function (CDF), dengan menggunakan data Survei Industri Besar dan Sedang (IBS) tahun 2003-2014. Kajian ini menemukan bahwa efek kompetisi yang dihasilkan akibat penurunan tarif impor output akan meningkatkan probabilitas perusahaan untuk keluar dari pasar. Namun penurunan tarif impor input akan menurunkan probabilitas perusahaan untuk keluar dari pasar. Setelah mendisagregasi perusahaan berdasarkan beberapa karakteristik yang dapat diobservasi diperoleh bahwa perusahaan yang memproduksi barang konsumsi, perusahaan dalam industri yang padat karya, perusahaan kecil, dan perusahaan yang terdapat pada industri yang lebih kompetitif memiliki peluang utuk keluar dari pasar lebih tinggi. Kajian ini merekomendasikan penetapan kebijakan tarif impor perlu dikaji baik dari sisi jenis komoditi maupun dari sisi karakteristik perusahaan.
\end{abstract}

Kata Kunci: Liberalisasi Tarif Impor, Seleksi Pasar, Probabilitas Perusahaan Keluar

\begin{abstract}
Theoretically, the impact of output and input import tarif on firm's performance is different, however this have never been shown empirically in Indonesia. This study aims at examining the effect of input and output tarifs on the possibility of firms to exit. Study utilized probit model which is considered as one of the Cummulative Distribution Function (CDF) Model by Indonesian Manufacturing Firms Data from 2003-2014 it was found that competition effects resulting from lower output tarifs exerts greater impact on the likelihood of exit but decreasing input tarifs will actually reduce the probability of exit firms. After classifying our sample into a different group based on observed characteristics of industry and firm, we found firms that produce consumer good, labor intensive firm, small firms, firms in competitive industry have a higher probability to exit. The study suggested that import tariff policy needs to be assessed both in terms of commodity types and in terms of firm characteristics.
\end{abstract}

Keywords: Import Tarif Liberalization, Market Selection, Firm Exit

JEL Classification: F13, L25, O24

PENDAHULUAN

Teori ekonomi menunjukkan

bahwa dampak tarif impor barang output

dan barang input terhadap kinerja perusahaan berbeda (Luong, 2011).

Tarif impor output bagi perusahaan berfungsi sebagai pelindung nilai tambah sementara tarif impor input 
berfungsi sebagai faktor penambah biaya produksi (Corden, 1971). Namun, penetapan kebijakan tarif impor terjadi simetris di suatu negara tanpa membedakan apakah barang tersebut digunakan sebagai input antara bagi suatu perusahaan atau barang tersebut merupakan hasil (output) suatu perusahaan. Rodrik (1988) dan Melitz (2003) menjelaskan dampak tarif impor sebagai output terhadap kinerja perusahaan. Rodrik (1988) mengatakan penurunan tarif impor sebagai bentuk dari liberalisasi perdagangan suatu negara akan berdampak pada menurunnya produktivitas perusahaan dan menyebabkan perusahaan keluar dari pasar. Model teori yang dibangun oleh Melitz (2003) membenarkan teori Rodrik (1988) bahwa penurunan tarif akan menyebabkan market selection, ada perusahaan yang keluar dari pasar akibat efek kompetisi. Namun dibawah asumsi heterogenitas perusahaan, mereka yang keluar dari pasar adalah perusahaan yang memiliki produktivitas relatif rendah. Grossman \& Helpman (1990) melihat tarif dari sisi input. Ketika terjadi liberalisasi perdagangan, hal ini memungkinkan perusahaan untuk mendapatkan teknologi dari negara lain secara tidak langsung melalui barang inputnya. Sehingga produktivitas perusahaan akan meningkat akibat penggunaan variasi input yang semakin bertambah atau peningkatan kualitas input yang digunakan (Acemoglu \& Zilibotti, 2001; Koren \& Tenreyro, 2007). Model teori yang secara bersama-sama membuktikan bahwa kedua dampak tarif impor output dan input tersebut berbeda terhadap kinerja perusahaan dibangun oleh Luong (2011). Namun, secara empiris belum banyak literatur yang telah membuktikan adanya dampak berlawanan tersebut.

Studi empiris yang membahas dampak penurunan tarif impor terhadap kinerja perusahaan sebagian besar menggunakan variabel produktivitas perusahaan sebagai dependent variable (Amiti \& Konings, 2007; Pavcnik, 2002; Schor, 2004). Namun belum begitu banyak yang mengukur kinerja perusahaan melalui variabel probabilitas perusahaan keluar. Menurut Melitz (2003) sebuah perusahaan akan keluar dari pasar ketika produktivitas profit perusahaan bernilai negatif atau produktivitas perusahaan cenderung rendah. Sehingga probabilitas perusahan dapat digunakan sebagai variabel yang mencerminkan kinerja sebuah 
perusahaan. Sejauh yang penulis tahu terdapat beberapa penelitian yang membahas mengenai dampak tarif impor terhadap probabilitas perusahaan keluar dari pasar, diantaranya Baggs (2005); Eslava, Haltiwanger, Kugler, \& Kugler, (2013); Mao \& Sheng (2017a). Namun dari studi empiris tersebut sebagian besar masih terfokus pada tarif impor barang akhir atau tarif impor output (Baggs, 2005; Eslava et al., 2013; Pavcnik, 2002; Schor, 2004). Sementara Amiti \& Konings (2007) telah mengkaji melalui data Indonesia jika variabel tarif impor input tidak digunakan disamping variabel tarif impor output sebagai variabel penjelas akan menyebabkan omitted variable bias. Hal ini disebabkan tarif impor input berkorelasi terhadap tarif impor output dan secara teori memiliki dampak terhadap kinerja perusahaan.

Probabilitas perusahaan untuk keluar dari pasar merupakan hal yang belum banyak diteliti di Indonesia. Penelitian mengenai probabilitas perusahaan untuk keluar dari pasar ini menjadi penting untuk kasus Indonesia karena Bartelsman, Haltiwanger, \& Scarpetta (2004) dalam penelitiannya telah membuktikan bahwa Indonesia merupakan salah satu negara dimana proses creative destruction (terutama perusahaan yang keluar dari pasar) memegang peranan penting dalam penciptaan produktivitas industri di tingkat agregat. Sementara itu Narjoko (2009) dalam penelitian empirisnya mengatakan, tarif impor memang memiliki dampak kuat pada rasio perusahaan yang masuk dan keluar pasar,di tingkat industri di Indonesia, namun masih belum dapat dideskripsikan dengan pasti apakah penurunan tarif ini berdampak positif atau negatif terhadap keluar masuknya perusahaan. Sehingga dibutuhkan penelitian di tingkat perusahaan yang lebih rinci mengenai apakah penurunan tarif impor berdampak pada keputusan perusahaan untuk keluar dari pasar. Dalam penelitian ini penulis akan memasukkan variabel tarif impor input disamping penggunaan tarif impor output. Di Indonesia belum terdapat penelitian serupa, penelitian terdekat dengan studi yang akan dilakukan penulis adalah penelitian yang dilakukan oleh Mao \& Sheng (2017a) menggunakan data industri besar sedang di negara China. Namun pada penelitian tersebut juga belum berhasil membuktikan adanya dampak berlawanan yang ditimbulkan tarif impor 
input dan output terhadap kinerja perusahaan dari sisi probabilitas perusahaan untuk keluar dari pasar.

Tulisan ini dibagi dalam beberapa bagian. Bagian pertama berupa pendahuluan berisi tentang latar belakang, studi literatur dan gap penelitian ini. Bagian metode menjelaskan jenis data, cara identifikasi variabel melalui data, serta metode analisis yang digunakan. Bagian ketiga dan keempat berisi hasil dan pembahasan. Akhirnya di bagian empat diberikan kesimpulan dan rekomendasi kebijakan dari penelitian ini.

\section{METODE}

Untuk mengestimasi dampak tarif impor output dan input terhadap probabilitas keluar dari pasar, studi ini menggunakan model probit. Model probit merupakan salah satu model dari cummulative distribution function (CDF). Model ini digunakan untuk menganalisis model dengan variabel dependen yang memiliki hasil binary, yaitu $\mathrm{y}=1$ untuk menandakan suksesnya sebuah kejadian, dan $\mathrm{y}=0$ untuk menandakan gagalnya sebuah kejadian. Untuk membangun model probit, dimisalkan kondisi dari sejumlah i perusahaan pada periode $\mathrm{t}-1$ untuk keluar dari pasar atau tidak, tergantung pada utility index, $I_{i}$ yang tidak teramati. $I_{i}$ didefinisikan sebagai berikut (Gujarati, 2004):

$I_{i}=\beta_{1}+\beta_{2} X_{i}$

Utility index yang tidak teramati ini terkait dengan kondisi keluar perusahaan dari pasar dapat dijelaskan sebagai berikut. Misalkan $Y=1$ jika perusahaan memilih untuk keluar dari pasar dan $\mathrm{Y}=0$ jika perusahaan tetap atau non response di beberapa periode penelitian. Probabilitas perusahaan untuk keluar dari pasar merupakan salah satu variabel pengukur kinerja perusahaan yang belum banyak diteliti di Indonesia. Literatur studi terdahulu mengidentifikasi perusahaan yang keluar dari pasar berdasarkan keberadaan perusahaan pada dua periode berdekatan (Mao \& Sheng, 2017a Amiti \& Konnings, 2007; Baggs, 2005). Jika suatu perusahaan ada di periode $\mathrm{t}$ sementara pada periode $\mathrm{t}+1$ perusahaan tersebut tidak ada, maka diidentifikasi sebagai exit pada tahun $t+1$. Cara ini memiliki kekurangan jika diterapkan dalam data Indonesia. Hal ini dikarenakan kesadaran pelaporan data statistik di Indonesia masih rendah dan penerapan Undang-Undang Statistik bagi perusahaan yang tidak memberi laporan masih kurang terlaksana. 
Sehingga ketika data perusahaan ada di periode $t$ namun tidak ada di periode $t+1$ tidak dapat serta merta dikatakan perusahaan tersebut keluar dari pasar, namun bisa jadi perusahaan tidak melaporkan datanya ke Badan Pusat Statistik (non response). Dalam penelitian ini gunakan cara yang berbeda untuk menghindari selection bias dalam mengidentifikasi perusahaan keluar dibandingkan penelitian yang sudah ada sebelumnya. Perusahaan dikatakan keluar dari pasar jika perusahaan tidak ada minimal dalam dua tahun ke depan hingga tahun 2014. Hal ini menyebabkan, perusahaan yang non response pada periode-periode tertentu tidak tergolong perusahaan yang keluar dari pasar.

Dalam model ekonometrik identifikasi $Y=1$ dan $Y=0$ dapat dianggap terdapat suatu nilai kritis yaitu $I_{i}^{*}$, jika nilai kritis $I_{i}^{*}$ lebih rendah atau sama dengan utility index $I_{i}$, maka perusahaan akan keluar dari pasar, atau sebaliknya. Probabilitas $I_{i}^{*} \leq I_{i}$, dapat dihitung dari standar normal CDF:

$$
\begin{aligned}
P_{i}=P(Y=1 \mid X) & =P\left(I_{i}^{*} \leq I_{i}\right)=P\left(Z_{i} \leq\right. \\
\left.\beta_{1}+\beta_{2} X_{i}\right) & =F\left(\beta_{1}+\beta_{2} X_{i}\right) \ldots \ldots \ldots \ldots
\end{aligned}
$$

Dimana $P(Y=1 \mid X)$ adalah probabilitas kejadian terjadi pada nilai $X$ yang tetap dan dimana $Z_{i}$ adalah variabel standar normal. $\mathrm{F}$ adalah standar normal CDF. Model matematis Probit sebagai berikut:

$$
\begin{aligned}
F\left(I_{i}\right)= & \frac{1}{\sqrt{2 \pi}} \int_{-\infty}^{I_{i}} e^{-z^{2} / 2} d z= \\
& \frac{1}{\sqrt{2 \pi}} \int_{-\infty}^{\beta_{1}+\beta_{2} X_{i}} e^{-z^{2} / 2} d z
\end{aligned}
$$

Karena $\mathrm{P}$ merupakan probabilitas bahwa suatu peristiwa akan terjadi. Dalam penelitian ini $P$ adalah probabilitas perusahaan untuk keluar dari pasar, dengan nilai standar normal pada perusahaan adalah diantara $-\infty$ dan $I_{i}$.

Untuk mendapatkan informasi mengenai utility index $I_{i}$, serta $\beta_{1}$ dan $\beta_{2}$, maka dilakukan inverse dari CDF normal (persamaan 4).

$$
\begin{gathered}
I_{i}=F^{-1}\left(I_{i}\right)=F^{-1}\left(P_{i}\right)=\beta_{1}+\beta_{2} X_{i} . \\
\text { Mao } \& \text { Sheng }
\end{gathered}
$$

menggunakan model empiris berupa lag satu tahun untuk mengatasi adanya bias simultan dan hubungan timbal balik antara tarif impor dan probabilitas perusahaan untuk keluar dari pasar. Pada penelitian ini identifikasi keluarnya perusahaan pada periode $t+1$, sehingga penggunaan variabel independen pada periode $\mathrm{t}$ sudah merupakan model dengan lag satu tahun.

Strategi empiris pertama hanya memasukkan variabel independen berupa tarif impor output seperti yang dilakukan Amiti \& Konnings (2007) 
untuk dapat melihat perbedaan koefisien ketika dalam model menggunakan tarif impor output dan tarif impor input sebagai variabel independen secara bersamaan.

$P\left(Y_{i t}=1 \mid Y_{i t-1}=1\right)=\Lambda\left(\alpha_{0}+\alpha+\beta_{1} T O_{i t}+\right.$ $\left.\varepsilon_{i t}\right)$

Dimana $y_{i t}$ merupakan 1 jika perusahaan $i$ keluar pada $t+1$ hingga akhir periode penelitian (tahun 2014) dan 0 jika lainnya. $T O_{i t}$ merupakan tarif impor output perusahaan $i$ di tahun $t$. Model ini sudah menggunakan lag satu tahun untuk menghindari endogenitas dan memberikan waktu pada perusahaan untuk keluar dari pasar akibat adanya penurunan tarif. $\varepsilon_{i t}$ adalah error term yang terdistribusi sama dan saling independen.

Strategi empiris kedua adalah dengan memasukkan variabel tarif impor input ke dalam model. Hal ini untuk membuktikan adanya over omitted bias yang secara empiris ditunjukkan pada model empiris

$P\left(Y_{i t}=1 \mid Y_{i t-1}=1\right)=\Lambda\left(\alpha_{0}+\alpha+\beta_{1} T O_{i t}+\right.$ $\left.\beta_{2} T I_{i t}+\varepsilon_{i t}\right)$

Dimana $T I_{i t}$ merupakan tarif intermediate input pada perusahaan i berdasarkan kode KBLI yang bersesuaian di tahun $t$. Dalam penelitian ini penulis juga akan mengikuti cara pengukuran tarif intermediate input yang dilakukan Amiti dan Konings (2007) dengan data yang berbeda, yaitu menggunakan Tabel IO 2010 berbasis Tabel Penggunaan dan Penyediaan (TPP) 2010. Tabel IO 2010 ini memiliki struktur input yang lebih rinci dan disusun berdasarkan struktur input establishment. Pada tabel penyediaan dan penggunaan 2010 secara lebih rinci telah disusun besaran produk yang digunakan setiap industri sehingga penggunaan struktur input melalui tabel ini lebih baik dalam menaksir tarif impor input industri di Indonesia. Tarif impor input yang dibangun menggunakan rata-rata tertimbang dari tarif barang output di level 3 digit KBLI. Pengukuran tarif impor input tersebut adalah:

$T I_{k t}=\sum_{j} w_{j k} \times T O_{j}$

Dimana $T I_{k t}$ adalah tarif impor barang input industry $k$ pada tahun $\mathrm{t}$, dan $T O_{k t}$ adalah tarif impor output produk j pada tahun $\mathrm{t}$, sementara $w_{j k}$ adalah proporsi produk j sebagai input antara di industri k. Sebagai contoh industri kendaraan bermotor menggunakan $70 \%$ besi dan $30 \%$ karet maka tarif impor input industri kendaraan bermotor adalah $70 \%$ dari tarif besi ditambah dengan 30\% tarif impor output karet. 
Pada model empiris selanjutnya masukkan variabel independen berupa karakteristik perusahaan. $\mathrm{Hal}$ ini mengikuti penelitian Baggs (2005) yang mengatakan bahwa secara garis besar terdapat dua hal yang memengaruhi probabilitas perusahaan untuk keluar dari pasar yaitu faktor eksternal yang memengaruhi iklim kompetisi perusahaan di suatu industri dan faktor internal berupa karakteristik perusahaan.

Model empiris yang memasukkan karakteristik perusahaan sebagai variabel kontrol dalam penelitian ini adalah:

$P\left(Y_{i t}=1 \mid Y_{i t-1}=1\right)=\Lambda\left(\alpha+\beta_{1} T O_{i t}+\right.$ $\beta_{2} T I_{i t}+\beta_{3} \ln T K_{i t}+\beta_{3} \ln w_{i t}+\beta_{4} H I_{i t}+$ $\left.\beta_{5} \operatorname{Prod}_{i t}+\varepsilon_{i t}\right)$

Dimana $\ln T K_{i t}$ merupakan logaritma natural dari jumlah tenaga kerja produksi dan non produksi di perusahaan $i$ pada tahun $t$, $\ln w_{i t}$ merupakan logaritma natural dari pengeluaran pekerja perusahaan i pada periode $t$, dan $H I_{i t}$ merupakan indeks konsentrasi dari perusahaan i pada periode $t$ di 2 digit KBLI.

Variabel tenaga kerja digunakan sebagai indikator dari size perusahaan. Dunne, Roberts, \& Samuelson (1988) menemukan bahwa rasio perusahaan yang keluar dari pasar berkorelasi positif dengan size perusahaan tersebut. Variabel ini digunakan untuk mengontrol kemungkinan perusahaan melakukan ekspansi. Semakin banyak tenaga kerja di suatu perusahaan semakin besar perusahaan tersebut. Koefisien dari tenaga kerja diperkirakan bertanda negatif. Semakin tinggi size sebuah perusahaan maka output dan market share-nya juga semakin besar. Hal ini menyebabkan profit perusahaan makin tinggi sehingga makin kecil peluangnya untuk keluar dari pasar. Sebaliknya jika semakin kecil tenaga kerja di suatu perusahaan maka akan semakin besar peluangnya keluar dari pasar.

Variabel pengeluaran tenaga kerja pada penelitian ini digunakan sebagai indikator dari upah. Semakin tinggi pengeluaran tenaga kerja di suatu perusahaan maka marginal cost perusahaan tersebut semakin tinggi. Marginal cost yang tinggi akan mengurangi surplus usaha perusahaan tersebut. sehingga semakin kecil surplus usaha suatu perusahaan akan mengakibatkan semakin tingginya peluang perusahaan untuk keluar dari pasar (Luca \& Luca, 2017). Koefisien dari variabel pengeluaran tenaga kerja akan bertanda positif. 
HI menggambarkan indeks konsentrasi suatu industri. Penulis juga mengontrol mark up yang dilakukan perusahaan dengan memasukkan variabel Herfindahl indeks $(\mathrm{HI})$ dalam model empiris. Dalam hal ini gunakan 2 digit KBLI atau pengelompokan berdasarkan sektor. Semakin mendekati nilai 0 indeks $\mathrm{HI}$ maka semakin tinggi kompetisi pada industri tersebut, sebaliknya semakin tinggi nilai HI maka semakin terkonsentrasi suatu industri. Produsen yang berada pada industri yang terkonsentrasi lebih dapat memberikan mark up pada harga barang (Amiti \& Konings, 2007). Ketika harga barang semakin tinggi akibat mark up maka surplus usaha dari suatu perusahaan bertambah tinggi. Perusahaan dengan profit yang tinggi akan lebih mudah survive dalam suatu pasar. Sehingga koefisien dari $\mathrm{HI}$ diperkirakan akan bertanda negatif artinya semakin besar kompetisi di suatu industri maka semakin besar peluangnya untuk keluar dari pasar. Jadi hipotesis kedua dalam penelitian ini adalah variabel tenaga kerja, indeks konsentrasi, dan produktivitas akan berdampak negatif terhadap probabilitas perusahaan untuk keluar dari pasar sedangkan variabel pengeluaran tenaga kerja akan berdampak positif terhadap probabilitas perusahaan untuk keluar dari pasar.

Berdasarkan teori Grossman \& Helpman (1990), perusahaan dapat mengambil manfaat dari penurunan tarif impor input jika menggunakan input yang diimpor dari luar negri. Hal ini menyebabkan perusahaan dapat menyerap teknologi yang ada pada input tersebut. Sehingga penulis menggunakan variabel share impor dan memoderasikannya dengan variabel tarif impor input. Koefisien dari variabel share impor akan bertanda negatif karena diperkirakan probabilitas perusahaan keluar dari pasar akan semakin rendah ketika lebih banyak menggunakan input impor. Sedangkan koefisien variabel moderasi share impor dan tarif impor input diperkirakan akan bertanda positif. Hal ini berarti penurunan tarif impor input akan lebih menguntungkan perusahaan yang menggunakan impor intermediate input karena besarnya share impor akan semakin mengurangi probabilitas perusahaan untuk keluar dari pasar.

Produktivitas dan keputusan perusahaan untuk keluar dari pasar memiliki hubungan yang berkebalikan (Bernard, Eaton, Jensen, \& Kortum, 
2003; Henderson \& Kuncoro, 1996; Melitz, 2003; Schor, 2004). Perusahaan yang keluar dari pasar adalah perusahaan yang kurang efisien atau memiliki produktivitas rendah. Untuk mengontrol hal tersebut masukkan variabel produktivitas tenaga kerja dan interaksikan dengan variabel tarif impor input. Koefisien variabel produktivitas tenaga kerja diperkirakan akan bertanda negatif sehingga semakin produktif suatu perusahaan maka semakin kecil probabilitasnya untuk keluar dari pasar. Sedangkan koefisien dari variabel moderasi tarif impor input dan produktifitas diperkirakan akan bertanda positif artinya perusahaan yang lebih produktif akan lebih diuntungkan dari adanya penurunan tarif impor input. Semakin produktif suatu perusahaan dan semakin tinggi penggunaan input impornya maka semakin besar lagi mafaat penurunan tarif impor input yang didapatkan. Sehingga model empiris menjadi:

$$
\begin{aligned}
& P\left(Y_{i t}=1 \mid Y_{i t-1}=1\right)=\Lambda\left(\alpha+\beta_{1} T O_{i t}+\right. \\
& \beta_{2} T_{i t}+\beta_{3} \ln T K_{i t}+\beta_{3} \ln w_{i t}+\beta_{4} H_{i t}+ \\
& \beta_{5} \operatorname{Prod}_{i t}+\beta_{6} T I_{i t} * \operatorname{Prod}_{i t}+\beta_{7} T I_{i t} * \\
& \left.S_{i t}+\beta_{8} S_{i t}+\varepsilon_{i t}\right) \ldots \ldots \ldots \ldots \ldots \ldots \ldots \ldots \ldots . . .(9
\end{aligned}
$$

Terinspirasi dari Schor (2004) penulis akan mengeksplor bagaimana probabilitas perusahaan keluar dari pasar pada berbagai jenis industri diantaranya berdasarkan produk yang dihasilkan, berdasarkan teknologi yang digunakan, berdasarkan indeks konsentrasi industri, dan berdasarkan size perusahaan. Berdasarkan tipe barang yang diproduksi industri dibagi menjadi:

a. Capital good industry yaitu industri yang menghasilkan barang modal.

b. Intermediate good industry yaitu industri yang menghasilkan barang input antara.

c. Transport good industry yaitu industri yang menghasilkan alat angkutan.

d. Consumer good industry yaitu industri yang menghasilkan barang konsumsi.

Berdasarkan teknologi yang digunakan industri dibagi menjadi:

a. Capital intensive industry yang lebih banyak menggunakan modal uang dan finansial untuk menghasilkan suatu barang atau jasa.

b. Labor intensive industry yang lebih banyak menggunakan tenaga kerja untuk menghasilkan suatu barang atau jasa (industri padat karya).

c. Natural resouces industry, industri yang bahan bakunya dari alam.

Perusahaan dikatakan berada pada industri yang terkonsentrasi jika 
nilai $\mathrm{HI}$-nya di atas nilai median $\mathrm{HI}$ dan perusahaan dikatakan berada pada industri yang tidak terkonsentrasi jika nilai $\mathrm{HI}$-nya di bawah nilai median $\mathrm{HI}$. Berdasarkan ukuran bagi perusahaan kecil adalah perusahaan yang memiliki tenaga kerja kurang dari atau sama dengan 50 orang dan perusahaan besar merupakan perusahaan dengan tenaga kerja lebih dari 50.

\section{HASIL DAN PEMBAHASAN}

\section{Identifikasi Perusahaan Keluar}

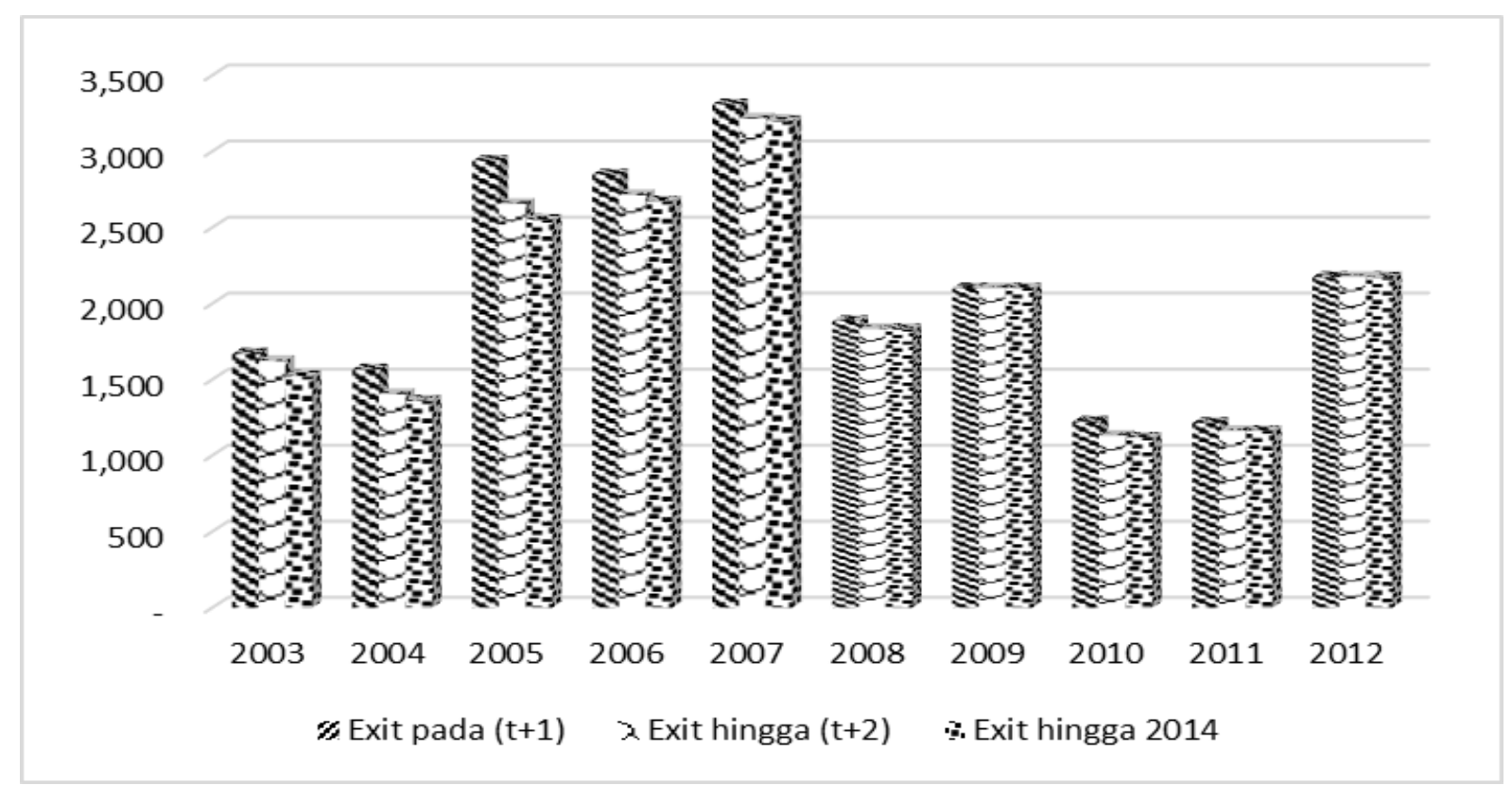

\section{Gambar 1. Jumlah Perusahaan Keluar 2001-2012}

Sumber: BPS (2001-2014), diolah

Gambar 1 dapat dilihat jumlah perusahaan keluar dan masuk berdasar beberapa definisi. Definisi pertama perusahaan dinyatakan keluar jika pada tahun $\mathrm{t}+1$ perusahaan tidak ditemukan. Definisi ini sering kali digunakan oleh banyak penelitian dalam mengidentifikasi perusahaan yang keluar dari pasar (Amiti \& Konings, 2007; Eslava et al., 2013; Mao \& Sheng, 2017a). Definisi kedua memakai definisi perusahaan keluar dari pasar jika perusahaan tersebut tidak ada di periode $t+1$ dan $t+2$. Terlihat jumlah perusahaan yang keluar dari pasar berkurang. Selisih histogram (1) dan (2) merupakan jumlah non response pada tahun $t+1$ namun melaporkan data pada tahun $t+2$. Definisi ketiga digambarkan histogram ke-3 yaitu perusahaan dinyatakan keluar jika hingga tahun 2014 perusahaan tidak muncul kembali 
sebagai observasi. Dari Gambar 1 dapat dilihat bahwa trend dari setiap definisi menurun. Hal tersebut menunjukkan bahwa untuk data manufaktur Indonesia, memungkinkan perusahaan untuk tidak merespon kuesioner. Sehingga identifikasi perusahaan yang keluar dari pasar dalam penelitian ini memakai definisi ketiga yaitu perusahaan dinyatakan keluar jika hingga tahun 2014 perusahaan tidak muncul kembali sebagai observasi. Jika perusahaan ternyata non response hingga 2014 maka hal tersebut di luar cakupan dari penelitian ini.

\section{Pengukuran Tarif Intermediate Input}

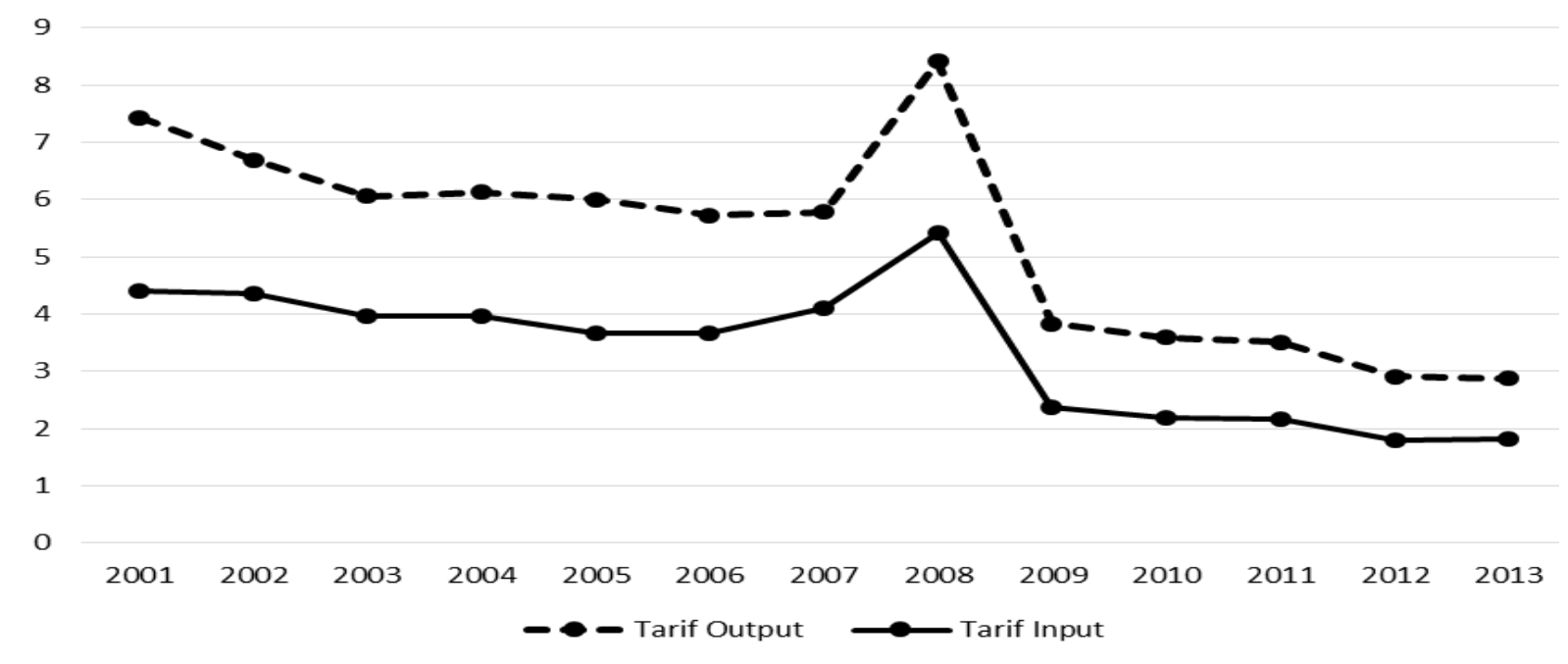

Gambar 2. Tarif Impor 2001-2013 di Indonesia (dalam persen)

Sumber: World Bank (2017)

Gambar 2 menyajikan hasil perhitungan mengenai rata-rata tarif impor Ad Valorem menggunakan struktur input dalam tabel IO 2010. Struktur tarif impor input dan tarif impor output pada Tabel 1 tidak terlalu jauh berbeda dibandingkan struktur tarif yang disajikan pada penelitian Amiti \& Konnings (2007). Hanya saja periode penelitian yang berbeda menyebabkan sebagian besar tarif pada penelitian
Amiti \& Konnings (2007) masih lebih dari $10 \%$. Hal ini juga menggambarkan bahwa struktur input impor dari perusahaan industri di Indonesia tidak banyak mengalami perubahan selama 15 tahun.

Kebijakan penurunan tarif impor di Indonesia cukup simestris baik untuk barang output maupun untuk barang input Penurunan tarif impor di Indonesia dimulai pada tahun 1995, dimana 
Indonesia mulai masuk menjadi anggota World Trade Organization (WTO) dan berkomitmen menurunkan tarif impor hingga kurang dari 40\% (Amiti \& Konings, 2007). Setelah periode krisis 1998, penurunan tarif impor Indonesia mulai stabil, yaitu dari $9,53 \%$ di tahun 1998 turun hingga rata-rata 2,47\% di tahun 2013. Namun pada tahun 2004 dan 2008 tarif impor mengalami peningkatan yang cukup signifikan dikarenakan adanya "ASEAN Harmonized Tarif Nomenclature (AHTN)"(Takii, 2016).

Jika dilihat dari variabilitas tarif, pada KBLI 2 digit tarif impor output dan input memiliki variability yang sama. Namun pada KBLI 3 digit dan 5 digit tarif impor input dan output mulai lebih bervariasi. Hal ini terbukti dari nilai korelasi antara tarif impor output dan input sebesar 0,407 . Sehingga akan terjadi omitted variable bias jika suatu penelitian dampak penurunan tarif terhadap kinerja perusahaan tidak memasukkan tarif impor input sebagai variabel penjelas disamping tarif impor output.

\section{Analisis Hasil Estimasi}

Hasil estimasi persamaan regresi menggunakan model logit dengan pooling data. Pada kolom pertama model estimasi logit hanya memasukkan tarif impor output (Persamaan 5), selanjutnya pada kolom kedua model estimasi memasukkan tarif impor input (Persamaan 6). Tarif impor output menunjukkan tanda signifikansi ketika dikontrol oleh variabel penjelas tarif impor input, dimana tarif impor input dan output memiliki tanda yang berlawanan terhadap probabilitas exit perusahaan. Hal ini juga membuktikan adanya omitted variabel bias jika tarif impor output tidak dikontrol menggunakan tarif impor input. Pada hasil estimasi probabilitas exit perusahaan di Tabel 1, hampir seluruh model menyatakan adanya dampak berkebalikan antara tarif impor input dan tarif impor output. Dimana tarif impor input memiliki dampak positif terhadap probabilita exit perusahaan atau dengan kata lain ketika terjadi penurunan tarif impor input maka probabilita perusahaan untuk keluar dari pasar akan semakin kecil dan penurunan tarif output akan menurunkan probabilitas perusahaan untuk keluar dari pasar. Hal ini dikarenakan efek kompetisi dalam pasar akibat penurunan tarif output yang semakin meningkat. Sedangkan koefisien tarif impor input bertanda positif artinya penurunan tarif impor 
input akan menyebabkan perusahaan perusahaan untuk keluar dari pasar semakin produktif dan probabilitas akan semakin berkurang.

Tabel 1. Hasil Estimasi Probabilita Perusahaan Keluar

\begin{tabular}{|c|c|c|c|c|}
\hline Variabel & $(1)$ & $(2)$ & (3) & $(4)$ \\
\hline \multirow[t]{2}{*}{ Output_Tarif } & $(0.00067)$ & $-0.00357^{* *}$ & $-0.00484^{* *}$ & $-0.00831^{* * *}$ \\
\hline & $(0.0016)$ & $(0.0018)$ & $(0.0019)$ & $(0.00243)$ \\
\hline \multirow[t]{2}{*}{ Input_Tarif } & & $0.0180^{* * *}$ & 0.00783 & $-0.0223^{* * *}$ \\
\hline & & $(0.0045)$ & $(0.0048)$ & $(0.00665)$ \\
\hline \multirow[t]{2}{*}{$\ln (\mathrm{TK})$} & & & $-0.596^{* * *}$ & $-0.546^{\star \star \star}$ \\
\hline & & & $(0.0131)$ & $(0.01430)$ \\
\hline \multirow[t]{2}{*}{$\ln ($ upah) } & & & $0.0576^{* * *}$ & $0.0268^{\star \star \star}$ \\
\hline & & & $\begin{array}{c}(0.0073) \\
-389 \mathrm{e}-\end{array}$ & $(0.00885)$ \\
\hline \multirow[t]{2}{*}{ productivity } & & & $06^{* \star \star}$ & -0.00000121 \\
\hline & & & $(0.0000)$ & $(0.00000)$ \\
\hline \multirow[t]{2}{*}{ shareimpor } & & & $-0.615^{\star \star \star}$ & $-0.336^{\star \star \star}$ \\
\hline & & & $(0.1020)$ & $(0.10800)$ \\
\hline \multirow[t]{2}{*}{$\mathrm{HHI}$} & & & $-0.613^{* * *}$ & -0.00219 \\
\hline & & & $(0.0787)$ & $(0.09110)$ \\
\hline \multirow[t]{2}{*}{ productivity*Input_Tarif } & & & $6.69 \mathrm{e}-07^{* *}$ & 0.000000427 \\
\hline & & & $(0.0000)$ & $(0.00000)$ \\
\hline \multirow[t]{2}{*}{ shareimpor ${ }^{\star}$ Output_Tarif } & & & $0.231^{* \star *}$ & $0.210^{\star \star \star}$ \\
\hline & & & $(0.0237)$ & $(0.02520)$ \\
\hline \multirow[t]{2}{*}{ Constant } & $-2.410^{* * *}$ & $-2.450^{* * *}$ & $-0.561^{* * *}$ & $-0.676^{\star \star \star}$ \\
\hline & $(0.0109)$ & $(0.0148)$ & $(0.0465)$ & $(0.06240)$ \\
\hline Industry Effect & No & No & No & Yes \\
\hline Time Effect & No & No & No & Yes \\
\hline Observation & 239,655 & 239,655 & 239,202 & 239,202 \\
\hline
\end{tabular}

Keterangan: nilai di dalam kurung merupakan standar error; ${ }^{*}$ Signifikan pada level $10 \%$; ** Signifikan pada level 5\%; ** Signifikan pada level $1 \%$

Arah koefisien tarif impor input perusahaan tersebut menggunakan pada kolom (4) di Tabel 1 setelah dikontrol dengan dummy industri dan dummy tahun menunjukkan arah yang berbeda. Namun koefisien variabel moderasi bertanda positif yang terdapat pada kolom (4) menunjukkan bahwa benar tarif impor input akan memperkecil probabilitas perusahaan untuk keluar dari pasar jika input impor. Namun ketika sebuah perusahaan tidak mengimpor intermediate input, penurunan tarif input akan memiliki dampak sama dengan penurunan tarif output yaitu memperbesar peluang perusahaan untuk keluar dari pasar.

Variabel kontrol dalam model berupa logaritma natural dari upah, 
logaritma natural tenaga kerja, $\mathrm{HI}$ dan produktivitas tenaga kerja menunjukkan tanda sesuai teori yang telah penulis bahas pada bagian metodologi. Dimana variabel kontrol yang meningkatkan probabilitas perusahaan untuk keluar dari pasar adalah variabel upah yang mengontrol biaya perusahaan dan yang memper-kecil probabilitas perusahaan keluar adalah variabel tenaga kerja, produktivitas, indeks konsentrasi, dan besarnya share intermediate input yang diimpor perusahaan.

Model logit merupakan model non linear sehingga hasil regresi non linear hanya memperlihatkan arah dari dampak variabel penjelas terhadap variabel dependen. Pada tabel 2 diberikan rata-rata nilai marginal efek dari setiap variabel dependen menggunakan model pada tabel 1 kolom (4). Ketika semua variabel penjelas berada pada saat rata-rata, yaitu tarif impor output sebesar 5,18\%, tarif impor input 2,99\%, pertumbuhan upah 9,25\%, produktivitas tenaga kerja 3,1 juta per tahun, pertumbuhan jumlah tenaga kerja $4,15 \%$, dan indeks konsentrasi di suatu industri 0,005 maka peluang perusahaan untuk keluar dari pasar adalah sebesar $0,067 \%$. Model yang digunakan di sini memiliki ketepatan estimasi sebesar $91,79 \%$.

\section{Tabel 2. Efek Marjinal Variabel Penjelas}

\begin{tabular}{lrr}
\hline \multicolumn{1}{c}{ Variabel } & Efek Marjinal & Standar Eror \\
\hline Output_Tarif & $-0.0006066^{* * *}$ & 0.00018 \\
Input_Tarif & $-0.0016271^{* * *}$ & 0.00049 \\
In(TK) & $-0.0398313^{* * *}$ & 0.00065 \\
In(upah) & $0.0019559^{* * *}$ & 0.00105 \\
Productivity & $-0.0000000885^{* * *}$ & 0.00000 \\
shareimpor & $-0.024498^{* * *}$ & 0.00665 \\
HHI & -0.0001595 & 0.00789 \\
shareimpor*Input_Tarif & $0.0152955^{* * *}$ & 0.00184 \\
Productivity*Input_Tarif & 0.0000000312 & 0.00000 \\
Number of Observation & 239.202 & \\
Prob>chi2 & 0.0000 & \\
pseudo R2 & 0.0561 & \\
Estat Classifiction & $91.79 \%$ & \\
Log likelihood & -64114.064 & \\
\hline
\end{tabular}

Keterangan: Signifikan pada level 10\%; ${ }^{* *}$ Signifikan pada level $5 \%$; ${ }^{* *}$ Signifikan pada level $1 \%$ 
Nilai efek marjinal terlihat dari Tabel 2 dimana efek marjinal dari tarif impor input dipengaruhi oleh besarnya share impor perusahaan dan produktivitas perusahaan. Dari nilai marjinal tarif impor input terhadap peluang perusahaan untuk keluar dari pasar di atas ternyata share impor dan produktivitas memiliki pengaruh terhadap marginal efek dari tarif impor input. Sehingga ketika perusahaan tidak melakukan impor intermediate input penurunan tarif impor input justru akan meningkatkan probabilitas perusahaan untuk keluar dari pasar. Hal ini masih sesuai dengan studi Grossman \& Helpman (1990) dan Melitz (2003) dimana perusahaan akan mengalami peningkatan produktivitas melalui penambahan variasi input atau peningkatan kualitas input impor. Sehingga ketika perusahaan tidak mengimpor input dari luar diasumsikan perusahaan tidak menambah variasi input atau tidak melakukan inovasi untuk meningkatkan kualitas input. Hal tersebut menyebabkan perusahaan tersebut keluar dari pasar akibat kalah dari perusahaan yang memanfaatkan penurunan tarif dengan menggunakan input impor. Disamping itu efek marjinal dari tarif impor input juga dipengaruhi oleh produktivitas dengan arah koefisien positif. Artinya, semakin tinggi produktivitas perusahaan semakin mengurangi meningkatnya probability exit perusahaan akibat penurunan tarif impor input. Dari efek marjinal ini juga dapat kita maknai bahwa probabilitas perusahaan untuk keluar dari pasar mungkin berkurang akibat penurunan tarif meskipun tidak melakukan impor input jika produktivitasnya cukup tinggi.

\section{Uji Ketahanan Model (Robustness} Check)

Definisi perusahaan yang keluar dari pasar pada penelitian ini berbeda dengan penelitian sebelumnya yang ada (Amiti \& Konings, 2007; Baggs, 2005; Eslava et al., 2013; Mao \& Sheng, 2017a). Hal ini dikarenakan survey manufaktur di Indonesia bersifat voluntary, sehingga memungkinkan perusahaan tidak melaporkan usahanya (non response) dan hal tersebut telah dibuktikan penulis pada analisis deskriptif sebelumnya. Namun perlu dibuktikan apakah beberapa definisi exit yang digunakan merubah arah atau tanda dari koefisien variabel penjelas atau tidak.

Pada Tabel 3 terdapat hasil regresi dengan beberapa definisi exit yang berbeda-beda. Pada kolom (2) 
perusahaan dikatakan keluar jika pada tahun $(\mathrm{t}+1)$ perusahaan tidak ada dalam pasar, pada kolom (3) perusahaan dikatakan keluar jika pada tahun $t+1$ hingga $t+2$ perusahaan tidak ada dalam pasar, pada kolom (4) perusahaan dikatakan keluar dari pasar jika dari periode $(t+1)$ hingga tahun 2014 perusahaan tidak ada lagi dalam pasar. Sehingga selama periode penelitian 2003-2012 dimungkinkan perusahaan yang melakukan non response untuk muncul di beberapa tahun dan tidak teridentifikasi sebagai perusahaan yang keluar.
Tabel 3 menunjukkan hasil yang robust pada setiap kolom. Hanya saja marginal effect dari tarif impor input sedikit lebih tinggi untuk variabel tarif impor input. Sehingga dapat ditarik kesimpulan bahwa menggunakan beberapa definisi firm exit untuk setiap regresi tidak merubah arah dan besarnya dampak setiap variabel penjelas. Terkait dengan tingginya perusahaan yang masuk pada tahun 2006 perlu diperiksa apakah new entrant berpengaruh terhadap probabilitas perusahaan untuk keluar dari pasar.

\section{Tabel 3. Robustness Check dengan Beberapa Definisi Exit}

\begin{tabular}{|c|c|c|c|}
\hline Variabel & Exit s.d. $(\mathrm{t}+1)$ & Exit s.d. $(\mathrm{t}+2)$ & Exit s.d. 2014 \\
\hline$(1)$ & $(2)$ & (3) & $(4)$ \\
\hline \multirow[t]{2}{*}{ Output_Tarif } & $-0.00535^{* * *}$ & $-0.00512^{\star * \star}$ & $-0.00484^{* *}$ \\
\hline & $(0.0019)$ & $(0.0019)$ & $(0.0019)$ \\
\hline \multirow[t]{2}{*}{ Input_Tarif } & $0.00935^{* *}$ & 0.00749 & 0.00783 \\
\hline & $(0.0047)$ & $(0.0048)$ & $(0.0048)$ \\
\hline \multirow[t]{2}{*}{$\ln (T K)$} & $-0.600^{* * *}$ & $-0.599^{* \star *}$ & $-0.596^{\star * *}$ \\
\hline & $(0.0127)$ & $(0.0130)$ & $(0.0131)$ \\
\hline \multirow[t]{2}{*}{ In(upah) } & $0.0583^{* * *}$ & $0.0594^{* * *}$ & $0.0576^{* * *}$ \\
\hline & $(0.0071)$ & $(0.0072)$ & $(0.0073)$ \\
\hline \multirow[t]{2}{*}{ Productivity } & $-3.92 e-06^{\star * *}$ & $-4.14 \mathrm{e}-06^{\star * *}$ & $-3.89 e-06^{\star \star *}$ \\
\hline & $(0.0000)$ & $(0.0000)$ & $(0.0000)$ \\
\hline \multirow[t]{2}{*}{ shareimpor } & $-0.654^{\star * *}$ & $-0.624^{\star * *}$ & $-0.615^{\star * *}$ \\
\hline & $(0.1000)$ & $(0.1010)$ & $(0.1020)$ \\
\hline \multirow[t]{2}{*}{$\mathrm{HHI}$} & $-0.571^{* \star *}$ & $-0.604^{* * *}$ & $-0.613^{* * *}$ \\
\hline & $(0.0761)$ & $(0.0781)$ & $(0.0787)$ \\
\hline \multirow[t]{2}{*}{ Productivity*Input_Tarif } & $6.57 e-07^{* *}$ & $7.01 \mathrm{e}-07^{* *}$ & $6.69 \mathrm{e}-07^{* *}$ \\
\hline & $(0.0000)$ & $(0.0000)$ & $(0.0000)$ \\
\hline \multirow[t]{2}{*}{ shareimpor*Input_Tarif } & $0.229^{* * *}$ & $0.231^{* * *}$ & $0.231^{* * *}$ \\
\hline & $(0.0234)$ & $(0.0236)$ & $(0.0237)$ \\
\hline \multirow[t]{2}{*}{ Constant } & $-0.489^{* * *}$ & $-0.547^{* * *}$ & $-0.561^{* * *}$ \\
\hline & $(0.0452)$ & $(0.0462)$ & $(0.0465)$ \\
\hline Observations & 239,202 & 239,202 & 239,202 \\
\hline
\end{tabular}

Keterangan: nilai di dalam kurung merupakan standar error; ${ }^{*}$ Signifikan pada level 10\%;

** Signifikan pada level 5\%; ${ }^{* * *}$ Signifikan pada level $1 \%$ 
Pada tabel 4 menunjukkan hasil robustness check dengan menambahkan variabel kontrol waktu dan industri serta variabel jumlah perusahaan masuk berdasarkan KBLI 2 digit dan tahun. Pada kolom (2) variabel new entrant dimasukkan dalam model, ternyata arah dari koefisien new entrant bertanda negatif, hal ini berlawanan dengan teori Melitz \& Trefler (2012) yang menyatakan bahwa semakin tinggi kompetisi dalam suatu pasar (ditandai dengan semakin banyaknya perusahaan yang masuk) maka peluang perusahaan yang kurang produktif untuk keluar dari pasar juga semakin tinggi. Arah yang berkebalikan pada variabel new entrant di kolom (2) diduga disebabkan oleh data new entran yang outlier di 2006 akibat adanya Sensus Ekonomi yang dilaksanakan BPS pada tahun tersebut. Selanjutnya dilakukan meregresi model dengan mengeluarkan observasi di tahun 2006. Hasil kolom (3) menunjukkan regresi logit tanpa tahun 2006. Koefisien dari variabel new entran di kolom (3) bertanda positif artinya benar semakin tinggi kompetisi suatu industri maka hal tersebut akan meningkatkan probabilitas perusahaan untuk keluar dari pasar.

\section{Heterogenitas Perusahaan}

Penulis membandingkan heterogenitas perusahaan dalam meresponse adanya penurunan tarif menurut beberapa klasifikasi industri yang dapat diobservasi, diantaranya tipe produk yang dihasilkan (kolom 2), faktor intensitas di suatu industri (kolom 3), size perusahaan (kolom 4), dan indeks konsentrasi industri (kolom 5). Pada Tabel 5 dapat lihat hasil estimasi logit dengan beberapa karakteristik perusahaan. Arah setiap koefisien variabel independen hampir sama untuk setiap kolom. Namun dalam hal ini penulis bertujuan melihat efek marjinal dari penurunan tarif impor output dan tarif impor input terhadap probabilitas perusahaan untuk keluar dari pasar berdasarkan beberapa karakteristik yang dapat di observasi. 
Tabel 4. Robustness Check dengan Kontrol Variabel New Entrant

\begin{tabular}{|c|c|c|c|}
\hline Variabel & $(1)$ & $(2)$ & $(3)$ \\
\hline Output_Tarif & $\begin{array}{c}-0.00831^{* * *} \\
(0.00243)\end{array}$ & $\begin{array}{c}-0.00837^{* * *} \\
(0.00243)\end{array}$ & $\begin{array}{c}-0.00908^{* * *} \\
(0.00269)\end{array}$ \\
\hline Input_Tarif & $\begin{array}{l}-0.0223^{* * *} \\
(0.00665)\end{array}$ & $\begin{array}{l}-0.0222^{\star * *} \\
(0.00665)\end{array}$ & $\begin{array}{l}-0.0198^{* * *} \\
(0.00712)\end{array}$ \\
\hline Inupah & $\begin{array}{l}0.0268^{* * *} \\
(0.00885)\end{array}$ & $\begin{array}{l}0.0269^{* * *} \\
(0.00885)\end{array}$ & $\begin{array}{c}0.00442 \\
(0.00921)\end{array}$ \\
\hline InTK & $\begin{array}{l}-0.546^{\star * *} \\
(0.01430)\end{array}$ & $\begin{array}{l}-0.546^{\star * *} \\
(0.01430)\end{array}$ & $\begin{array}{l}-0.519^{* * *} \\
(0.01510)\end{array}$ \\
\hline Productivity & $\begin{array}{c}-0.00000121 \\
(0.00000)\end{array}$ & $\begin{array}{c}-0.00000122 \\
(0.00000)\end{array}$ & $\begin{array}{c}-0.000000744 \\
(0.00000)\end{array}$ \\
\hline $\mathrm{HHI}$ & $\begin{array}{l}-0.00219 \\
(0.09110)\end{array}$ & $\begin{array}{c}0.00299 \\
(0.09110)\end{array}$ & $\begin{array}{c}-0.0297 \\
(0.09530)\end{array}$ \\
\hline shareimpor & $\begin{array}{l}-0.336^{\star \star *} \\
(0.10800)\end{array}$ & $\begin{array}{l}-0.335^{\star * *} \\
(0.10800)\end{array}$ & $\begin{array}{l}-0.418^{\star * *} \\
(0.11500)\end{array}$ \\
\hline Productivity*Input_Tarif & $\begin{array}{c}0.000000427 \\
(0.00000)\end{array}$ & $\begin{array}{c}0.000000429 \\
(0.00000)\end{array}$ & $\begin{array}{c}0.000000313 \\
(0.00000)\end{array}$ \\
\hline shareimpor*Input_Tarif & $\begin{array}{c}0.210^{* * *} \\
(0.02520)\end{array}$ & $\begin{array}{c}0.210^{* * *} \\
(0.02520)\end{array}$ & $\begin{array}{c}0.205^{* * *} \\
(0.02670)\end{array}$ \\
\hline New_entrant & & $\begin{array}{l}-1.4 \mathrm{E}-09 \\
(0.00000)\end{array}$ & $\begin{array}{c}3.20 \mathrm{e}-08^{* * *} \\
(0.00000)\end{array}$ \\
\hline Constant & $\begin{array}{l}-0.676^{\star \star \star} \\
(0.06240)\end{array}$ & $\begin{array}{l}-0.665^{* * *} \\
(0.06300)\end{array}$ & $\begin{array}{l}-0.695^{\star * *} \\
(0.07500)\end{array}$ \\
\hline Industry Effect & Yes & Yes & Yes \\
\hline Time Effect & Yes & Yes & Yes \\
\hline Observations & 239,202 & 239,202 & 209,924 \\
\hline
\end{tabular}

Keterangan: nilai di dalam kurung merupakan standar error, ${ }^{*}$ Signifikan pada level 10\%;

** Signifikan pada level 5\%; ${ }^{* *}$ Signifikan pada level $1 \%$

Berdasarkan nilai estimasi logit banyak yaitu 131.693 perusahaan karakteristik yang memiliki probabilitas lebih tinggi keluar dari pasar adalah perusahaan yang memproduksi barang konsumsi, perusahaan labor intensive, perusahaan kecil dan perusahaan dengan indeks konsentrasi rendah. Jika dianalisis data industri berdasarkan tipe produk yang dihasilkan, jumlah observasi yang tergolong industri yang menghasilkan produk konsumsi paling dengan share nilai tambah sebesar $38,48 \%$ pada periode 2003-2012. Selain itu persentase perusahaan keluar dari pasar di kelompok industri yang memproduksi barang konsumsi secara rata-rata pada tahun penelitian paling tinggi, namun perusahaan yang melakukan impor barang input pada kelompok ini lebih sedikit dibandingkan kelompok lain yaitu $13,26 \%$ dari 
131.693 perusahaan, sementara kelompok lain lebih dari $25 \%$ perusahaannya melakukan impor barang input. Hal ini merupakan salah satu penyebab tingginya probabilitas perusahaan untuk keluar dari pasar di kelompok industri yang menghasilkan barang konsumsi.
Perusahaan yang memiliki produktivitas tenaga kerja rendah di Indonesia justru identik dengan perusahaan yang memiliki faktor intensif tenaga kerja, sesuai dengan penelitian yang dilakukan oleh Xie (2017), hingga wajar perusahaan dengan karakteristik padat karya memiliki probabilitas keluar dari pasar lebih tinggi.

Tabel 5. Hasil Estimasi Logit Probabilitas Perusahaan Keluar dari Pasar

\begin{tabular}{|c|c|c|c|c|}
\hline Variabel & (1) & (2) & (3) & (5) \\
\hline \multirow[t]{2}{*}{ Output_Tarif } & -0.00153 & $-0.00952^{* * *}$ & $-0.00481^{* *}$ & $-0.00770^{* * *}$ \\
\hline & $(0.0017)$ & $(0.0022)$ & $(0.0019)$ & $(0.0020)$ \\
\hline \multirow[t]{2}{*}{ Input_Tarif } & $0.0129^{* \star *}$ & $0.00908^{*}$ & 0.00766 & 0.00749 \\
\hline & $(0.0048)$ & $(0.0051)$ & $(0.0048)$ & $(0.0049)$ \\
\hline \multirow[t]{2}{*}{ Inupah } & $0.0700^{* * *}$ & $0.0548^{* * *}$ & $0.0601^{* * *}$ & $0.0587^{* * *}$ \\
\hline & $(0.0075)$ & $(0.0075)$ & $(0.0073)$ & $(0.0073)$ \\
\hline \multirow[t]{2}{*}{ InTK } & $-0.603^{* * *}$ & $-0.596^{* * *}$ & $-0.492^{* * *}$ & $-0.598^{* * *}$ \\
\hline & $(0.0133)$ & $(0.0133)$ & $(0.0177)$ & $(0.0131)$ \\
\hline \multirow[t]{2}{*}{ LPoutput } & $-3.97 e-06^{* * *}$ & $-2.52 e-06^{* *}$ & $-3.60 \mathrm{e}-06^{* * *}$ & $-4.26 \mathrm{e}-06^{\star * *}$ \\
\hline & $(0.0000)$ & $(0.0000)$ & $(0.0000)$ & $(0.0000)$ \\
\hline \multirow[t]{2}{*}{$\mathrm{HHI}$} & $-0.258^{* * *}$ & $-0.326^{\star * *}$ & $-0.612^{* * *}$ & $-0.194^{* *}$ \\
\hline & $(0.0811)$ & $(0.0806)$ & $(0.0788)$ & $(0.0860)$ \\
\hline \multirow[t]{2}{*}{ shareimpor } & $-0.435^{\star * *}$ & $-0.572^{* * *}$ & $-0.609^{* * *}$ & $-0.586^{* * *}$ \\
\hline & $(0.1020)$ & $(0.1030)$ & $(0.1020)$ & $(0.1020)$ \\
\hline \multirow[t]{2}{*}{$\operatorname{modLP}$} & $8.29 \mathrm{e}-07^{* * *}$ & $5.39 \mathrm{e}-07^{*}$ & $6.27 \mathrm{e}-07^{*}$ & $7.81 \mathrm{e}-07^{* *}$ \\
\hline & $(0.0000)$ & $(0.0000)$ & $(0.0000)$ & $(0.0000)$ \\
\hline \multirow[t]{2}{*}{$\operatorname{modSI}$} & $0.210^{* * *}$ & $0.237^{* * *}$ & $0.229^{* * *}$ & $0.227^{* * *}$ \\
\hline & $(0.0238)$ & $(0.0240)$ & $(0.0237)$ & $(0.0238)$ \\
\hline \multirow[t]{2}{*}{ Consumer_prod } & $0.220^{* * *}$ & & & \\
\hline & $(0.0464)$ & & & \\
\hline \multirow[t]{2}{*}{ Intermediate_prod } & $-0.165^{\star * *}$ & & & \\
\hline & $(0.0467)$ & & & \\
\hline \multirow[t]{2}{*}{ Transport_prod } & $-0.250^{\star * *}$ & & & \\
\hline & $(0.0717)$ & & & \\
\hline \multirow[t]{2}{*}{ Labor_intensive } & & $0.365^{* * *}$ & & \\
\hline & & $(0.0313)$ & & \\
\hline \multirow[t]{2}{*}{ Resourcebase_industry } & & $0.171^{* * *}$ & & \\
\hline & & $(0.0317)$ & & \\
\hline \multirow[t]{2}{*}{ small_size } & & & $0.249^{* * *}$ & \\
\hline & & & $(0.0297)$ & \\
\hline \multirow[t]{2}{*}{ konsentrasi_rendah } & & & & $0.175^{* * *}$ \\
\hline & & & & $(0.0175)$ \\
\hline \multirow[t]{2}{*}{ Constant } & $-0.796^{\star \star *}$ & $-0.805^{\star \star *}$ & $-1.153^{\star \star \star}$ & $-0.656^{* * *}$ \\
\hline & $(0.0702)$ & $(0.0599)$ & $(0.0836)$ & $(0.0475)$ \\
\hline Observations & 239,202 & 239,202 & 239,202 & 239,202 \\
\hline
\end{tabular}

Keterangan: nilai di dalam kurung merupakan standar error; ${ }^{*}$ Signifikan pada level 10\%;

** Signifikan pada level 5\%; *** Signifikan pada level $1 \%$ 
Penelitian yang menemukan probabilitas perusahaan kecil lebih tinggi untuk keluar dari pasar adalah Sönmez (2013). Dengan menggunakan data manufaktur negara Turki ditemukan bahwa perusahaanperusahaan yang kecil dan baru memiliki tingkat kegagalan lebih tinggi untuk bertahan pada satu pasar. Dalam penelitian yang sama juga disebutkan berbagai sebab dari berbagai literatur mengapa perusahaan kecil memiliki peluang keluar lebih tinggi dibanding perusahaan besar. Hal tersebut disebabkan antara lain oleh kurangnya inovasi (Cefis \& Marsili, 2004), kurangnya modal (Evans \& Jovanovic, 1989), kemampuan perusahaan untuk meningkatkan harga atau menurunkan biaya (Görg \& Strobl, 2000), selain itu perusahaan kecil juga memiliki hubungan yang relatif kurang dekat dibandingkan perusahaan besar dengan lembaga keuangan seperti bank (Elston \& Agarwal, 2001).

Penggolongan

perusahaan

berdasarkan Herfindahl indeks adalah salah satu cara yang dilakukan untuk melihat heterogenitas perusahaan. Pada Tabel 5 kolom 5 disajikan hasil estimasi probabilitas perusahaan keluar dari pasar dengan menambahkan variabel kategorik berupa dummy herfindahl indeks. Perusahaan yang berada pada industri yang lebih terkonsentrasi pasti memiliki market power lebih tinggi dibandingkan perusahaan yang berada pada industri yang tidak terkonsentrasi. Amiti \& Konings (2007) menemukan bahwa semakin terkonsentrasi suatu industri maka produktivitasnya semakin rendah. Sehingga wajar saja perusahaan yang berada pada indeks konsentrasi rendah memiliki probabilitas keluar lebih tinggi dibandingkan perusahaan yang berada pada indeks konsentrasi tinggi.

\section{KESIMPULAN DAN REKOMENDASI KEBIJAKAN}

Penelitian ini mengestimasi dampak penurunan tarif impor sebagai bagian dari liberalisasi perdagangan di Indonesia terhadap peluang perusahaan untuk keluar dari pasar pada periode 2003-2012. Penelitian ini tidak hanya meneliti tentang penurunan tarif barang impor secara keseluruhan, tetapi juga melihat dampak tarif barang intermediate input yang diukur sebagai rata-rata tertimbang dari tarif impor output. Hasil estimasi menunjukkan tarif intermediate input dan tarif barang 
output memiliki dampak yang berlawanan sesuai dengan studi terdahulu.

Dampak positif dari penurunan tarif impor input terhadap kinerja perusahaan akan semakin tinggi ketika perusahaan menggunakan impor barang input atau memiliki produktivitas yang tinggi. Sehingga para pembuat kebijakan perlu memperhatikan ketika suatu tarif digunakan untuk memproteksi suatu industri pada saat yang sama bisa jadi hal ini akan mempertinggi biaya di industri atau perusahaan lain. Dan tidak heran ketika trade liberalisasi meningkatkan impor dalam negeri, karena penurunan tarif tidak hanya dimanfaatkan untuk mengimpor barang konsumsi akhir tetapi juga barang konsumsi antara bagi para produsen.

Penulis juga melihat dampak penurunan tarif impor input pada berbagai karakteristik perusahaan untuk melihat respon perusahaan berdasarkan heterogenitasnya. Dalam penelitian ini penulis menggolongkan perusahaan berdasarkan tipe barang yang diproduksinya, faktor intensitasnya, size perusahaan, dan tingkat konsentrasi industri. Karakteristik perusahaan yang memiliki peluang lebih besar untuk keluar dari pasar adalah perusahaan yang memproduksi barang konsumsi, perusahaan padat karya, perusahaan kecil, dan perusahaan yang berada pada industri yang lebih kompetitif. Sehingga penetapan kebijakan tarif seharusnya mempertimbangkan karakteristik perusahaan yang akan menggunakan produk tersebut.

Dalam beberapa literatur yang menggunakan probabilita exit perusahaan juga memasukkan produktivitas perusahaan di samping penurunan tarif impor. Literatur yang menggunakan produktivitas sebagai variabel dependen juga memasukkan variabel keputusan perusahaan untuk keluar dari pasar sebagai variabel penjelas. Sehingga terdapat isu ekonometrik dalam penelitian mengenai dampak tarif di level perusahaan, yaitu terdapat hubungan simultan antara produktivitas perusahaan dan probabilitas perusahaan untuk keluar dari pasar. Studi lanjutan diharapkan mampu menggunakan model empiris yang dapat mengatasi masalah endogenitas simultan yang terjadi antara produktivitas perusahaan dan probability exit perusahaan di dalam model ekonomi. 


\section{DAFTAR PUSTAKA}

Acemoglu, D., \& Zilibotti, F. (2001). Productivity Differences. The Quarterly Journals of Economics, (May), 563606.

Amiti, M., \& Konings, J. (2007). Trade Liberalization, Intermediate Inputs, and Productivity: Evidence from Indonesia. 9, 1611-1637.

Badan Pusat Statistik. (2017). Data Survey Industri Besar dan Sedang Tahun 2001-2014. Jakarta: BPS.

Baggs, J. (2005). Firm Survival and Exit in Response to Trade Liberalization. 38(4), 1364-1383.

Bartelsman, E., Haltiwanger, J., \& Scarpetta, S. (2004). Microeconomic evidence of creative destruction in industrial and developing countries. World Bank Working Paper Series, (1374). https://doi.org/-

Bernard, A. B., Eaton, J., Jensen, J. B., \& Kortum, S. (2003). Plants and Productivity in International Trade Plants and Productivity in International Trade. Source: The American Economic Review, 93112(4), 12681290. https://doi.org/10.2307/3132288

Cefis, E., Marsili, O. (2004). A Matter of Life and Death: Innovation or Firm Survival. Center for Research of Economic Microdata at Statistic Netherland. 1-26

Corden, W. M. (1971). The substitution problem in the theory of effective protection. Journal of International Economics, 1(1), 37-57. https://doi.org/10.1016/00221996(71)90015-8

Dunne, T., Roberts, M. J., \& Samuelson, L. (1988). Patterns of Firm Entry and Exit in U.S. Manufacturing Industries. The RAND Journal of Economics, 19(4), 495. https://doi.org/10.2307/2555454

Eslava, M., Haltiwanger, J., Kugler, A., \& Kugler, M. (2013). Trade and market selection: Evidence from manufacturing plants in Colombia. Review of Economic Dynamics, 16(1),
135-158.

https://doi.org/10.1016/j.red.2012.10.0 09

Elston, J., Agarwal, R. (2001). Conflicts of Interests Between German Universal Banks and Firms. Economic Letters vol 72. 225-232

Evans, D., Jovanovic, B. (1989). An Estimated Model of Entrepreneurial Choice Under Liquidity Constraints. Journal of Political Economy 97 (4). 808-827

Görg, H., Strobl, E. (2000). Multinational Companies, Technology Spillovers and Firm Survival: Evidence from Irish. ManufacturingCentre for Research on Globalisation and Labour Markets, School of Economics, Research Paper, University of Nottingham. 1-22

Grossman, G., \& Helpman, E. (1990). Trade, Knowledge Spillovers and Growth (No. 3485).

Gujarati, D. N. (2004). Basic Econometrics, fourth edition.McGraw-Hill Book Companies.

https://doi.org/10.1126/science.11868 74

Henderson, J. V., \& Kuncoro, A. (1996). Industrial Centralization in Indonesia. The World Bank Economic Review, 10(3), 513-540. Retrieved from http://www.jstor.org/stable/3990056

Koren, M., \& Tenreyro, S. (2007). CEP Discussion Paper No 824 October 2007 Technological Diversification. (824).

Luca, D. L., \& Luca, M. (2017). Survival of the Fittest: The Impact of the Minimum Wage on Firm Exit. Ssrn. https://doi.org/10.2139/ssrn.2951110

Luong, T. A. (2011). The Impact of Input and Output Tariffs on Firms Productivity: Theory and Evidence. Review of International Economics, 11(5), 821835. https://doi.org/10.1111/j.14679396.2011.00988.x

Mao, Q., \& Sheng, B. (2017a). The impact of tariff reductions on firm dynamics 
and productivity in China: Does marketoriented transition matter? China Economic Review, 45(October 2016), 168-194.

https://doi.org/10.1016/j.chieco.2017.0 7.011

Mao, Q., \& Sheng, B. (2017b). The impact of tariff reductions on firm dynamics and productivity in China: Does marketoriented transition matter? In China Economic Review. https://doi.org/10.1016/j.chieco.2017.0 7.011

Melitz, M. J. (2003). The Impact of Trade on Intra-Industry Reallocations and Aggregate Industry Productivity. Source: Econometrica, 71(6), 16951725. Retrieved from http://www.jstor.org/stable/1555536

Melitz, M. J., \& Trefler, D. (2012). Gains from Trade when Firms Matter. Journal of Economic Perspectives, 26(2), 91118.

https://doi.org/10.1257/jep.26.2.91

Narjoko, D. A. (2009). Plant Entry in a More Liberalised Industrialisation Process: An Experience of Indonesian Manufacturing during the 1990s. 356406. Retrieved from http://www.eria.org/publications/resear ch_project_reports/images/pdf/y2008/ no $1 /$ DEI-Ch $10 . p d f$
Pavcnik, N. (2002). Evidence from Chilean Plants. 69(1), 245-276. Retrieved from http://www.jstor.org/stable/2695960

Rodrik, D. (1988). Imperfect Competition , Scale Economies, and Trade Policy in Developing Countries. In Policy.

Schor, A. (2004). Heterogeneous productivity response to tariff reduction. Evidence from Brazilian manufacturing firms. Journal of Development Economics, 75(2 SPEC. ISS.), 373396.

https://doi.org/10.1016/j.jdeveco.2004. 06.003

Sönmez, A. (2013). Firm Entry, Survival, and Exit. Academic Journal of Interdisciplinary Studies, 2(9), 160167.

https://doi.org/10.5901/ajis.2013.v2n9 p160

Takii, S. (2016). Import Penetration, Export Orientation and Plant Size in Indonesian Manufacturing. In ERIA Research Project Report 2013-3, pp. VI-1-VI-24.

World Bank. (2017). Data Tarif Impor 20012013. Diunduh tanggal 20 Oktober 2017 dari www.wits.worldbank.org

Xie, V. W. (2017). Heterogeneous firms under regional temperature shocks: exit and reallocation, with evidence from Indonesia. 
70 | Buletin IImiah Litbang Perdagangan, VOL.13 NO.1, JULI 2019 